American Journal of Agricultural and Biological Sciences 6 (3): 393-402, 2011

ISSN 1557-4989

(C) 2011 Science Publications

\title{
Pyritization of the Coastal Sediments in the Kelantan Plains in the Malay Peninsula during the Holocene
}

\author{
M.S.K. Enio, J. Shamshuddin, C.I. Fauziah and M.H.A. Husni \\ Department of Land Management, Faculty of Agriculture, \\ University Putra Malaysia, 43400 UPM, Serdang, Selangor, Malaysia
}

\begin{abstract}
Problem statement: For a number of geological reasons a proportion of the present coastal plains in the Malay Peninsula were inundated by seawater in the past when pyrite in some of the soils is believed to have been mineralized. Random survey of these sites showed a unique distribution and depth of pyritic layer in the soils along the coastal plains. A study was conducted in order to explain the mechanism of pyritization in the sediments of the present day coastal plains in Kelantan, Peninsular Malaysia. Approach: Soil surveys were conducted and soils were sampled and analyzed. Spatial distribution of the pyritic soils was used to construct an imaginary line to indicate the probable position of the shoreline when the sea level was at its highest. Results: Results of the study showed that soils containing pyrite occur sporadically in the plains. This pyrite occurs in the soils at varying depth; some soils have pyritic layer below $2 \mathrm{~m}$ from the surface (northern region), while others have pyrite in the surface horizon (southern region). Pyrite was formed by the reaction of ferrous and sulfide ions which were respectively reduced from ferric ions (sediments) and sulfate (seawater) ions, respectively. In the middle of the study area, pyritic layer overlain by peaty materials were observed. Conclusion: The presence of pyrite in the soils can be used as an evidence for sea level rise in the area during the Holocene. This pyrite is assumed to have been formed about 6,000 years BP when the sea level rose 3$5 \mathrm{~m}$ above the present. Its oxidation has caused untold damage to the productivity of the paddy soils in the area.
\end{abstract}

Key words: Acid sulfate soil, peaty materials, jarosite mottles, coastal sediments, paddy soils, pedogenic pyrite, coastal plains, Kelantan Plains, Peninsular Malaysia, peaty materials, pyritic layer, Integrated Agricultural Development Project (IADP), treated clay fraction

\section{INTRODUCTION}

Soils which are classified as acid sulfate soils occur along the coastal plains of the Malay Peninsula (Shamshuddin, 2006) and Kalimantan, Indonesia (Anda et al., 2009). These soils are characterized by the presence of pedogenic pyrite $\left(\mathrm{FeS}_{2}\right)$, which is readily oxidized on exposure to atmospheric conditions, releasing sulfuric acid as well as $\mathrm{Al}^{3+}$ and $\mathrm{Fe}^{3+}$ into the environment which, in turn, affects plants and aquatic life. In the end a new stable mineral called jarosite $\left[\mathrm{KFe}_{3}(\mathrm{SO})_{2}(\mathrm{OH})_{6}\right]$ is formed (Shamshuddin and Auxtero, 1991; Shamshuddin et al., 2004a). When this straw yellow mineral appears in the soil profile, the $\mathrm{pH}$ is almost certainly below 3.5. In soil taxonomy (Soil Survey Staff, 2010), these soils are mostly classified as Sulfaquepts. The question is posed in this study-how has pyrite in the acid sulfate soils of the east coast states of Peninsular Malaysia come into being? This study will help explain in detail the mechanism of its formation.

Wan Noordin (1980) studied in detail some acid sulfate soils occurring in the west coast state of Peninsular Malaysia. Cocoa (Shamshuddin et al., 2004b) and oil palm (Auxtero and Shamshuddin, 1991; Mohd et al., 2009) grown on these soils have been found to suffer from $\mathrm{Al}$ toxicity. According to Wan Noordin (1980), remnants of diatoms were found in the sediments in close association with pyrite Fig. 1. We know that these diatoms were living creatures of the ocean. Hence, the areas where the acid sulfate soils occur were once inundated by seawater in order for the diatoms to survive. As such, we conclude that the formation of pyrite found in the soils under study is closely related to the sea.

Corresponding Author: J. Shamshuddin, Department of Land Management, Faculty of Agriculture, University Putra Malaysia, 43400 UPM, Serdang, Selangor, Malaysia Tel: +603-89466985 Fax: +603-89434419 


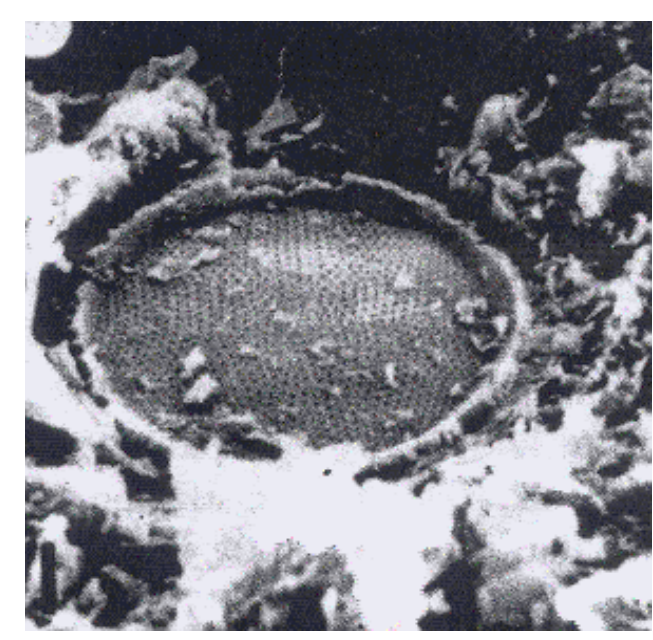

Fig. 1: Remnant of diatoms found in an acid sulfate soil of Malaysia, Courtesy of Wan Noordin Wan Daud Remnant of diatoms found in an acid sulfate soil of Malaysia

Early studies conducted in the east coast states of Peninsular Malaysia (Kelantan, Terengganu Pahang and Johor) found that some time during the Holocene, the sea level rose 3-5 $\mathrm{m}$ above the present high tide position (Tjia et al., 1977; Geyh et al., 1979). The progradation (Raj, 2009) of the sea years later led to the formation of sandy beach ridges running parallel to the present shoreline (Roslan et al., 2010). The occurrence of these sandy beach ridges along the coastal plains in the area has been used as evidence for sea level rise during the Holocene (Tjia, 1996; Eko Yulianto et al., 2004). Carbon dating of the oldest sediments in the ridges occurring in the Sunda Shelf (the area between the Malay Peninsula and Borneo Island) indicated their age to be about 6,000 years (Haile, 1970; Kefu and Tegu, 2009). This suggests that much of the present coastal plains in the east coast states of Peninsular Malaysia were once under the sea.

Acid sulfate soils have been found to occur sporadically in the Kelantan Plains (Soo, 1975; Shamshuddin, 2006). Based on the available soil maps at semi-detailed level, the government of Malaysia had established the Kemasin-Semerak Integrated Agricultural Development Project (IADP) in 1982 so as to alleviate severe poverty among the farming communities as well as for flood mitigation by constructing drainage canals. Many years later, some soils in the paddy fields were degraded due to excessive acidity caused by the oxidation of pyrite present in the soils (Suswanto et al., 2007a; 2007b). A soil survey carried out had redefined the area covered by these acid sulfate soils. However, further investigation was necessary in order to locate exactly the spatial distribution (including depth below the surface) of pyritic soils. A study was therefore conducted so as to explain the mechanism of the formation of pyrite in the Kelantan Plains, Peninsular Malaysia, to use pyrite spatial distribution in the area as evidence for the rise of sea level during the Holocene and to show that pyrite oxidation due to drainage is causing environmental damage to the surrounding areas.

\section{MATERIALS AND METHODS}

Location of the study area: The area under study is located in the Kemasin-Semerak Integrated Agricultural Development Project which is within the Kelantan Coastal Plains, Peninsular Malaysia Fig. 2. It is covered by $05.92584-05.99596^{\circ}$ north latitudes and between $102.40929^{\circ}$ and $102.37535^{\circ}$ east longitudes. This area was drained from 1982, for agricultural land use, leaving behind a partially drained area occupied by acid sulfate soils overlain by peaty materials, to be kept for further development later. This area is now covered by local plant species gelam (Melulueca leucadendron) and nipah (Nipa frutescens). These species thrive well under acidic conditions.

Field observations and soil sampling: All the published soil maps of the area under investigation were studied in detail before conducting the field work. For ease of movement, we used a four-wheel drive vehicle to comb the areas suspected of containing soils with pyrite in the Kemasin-Semerak IADP. We found, generally, that pyrite occurred at varying depths (close to the surface, below $2 \mathrm{~m}$ and in between the two). Additionally, the soils with pyrite at the study sites showed different degree of association with peaty materials (organic matter). At selected locations, soil samples were taken at $0-15,15-30,30-45$ and $45-60 \mathrm{~cm}$ depths using an auger. Three locations were specially marked for detailed study, designated as a, b and c, based on the depth of pyritic layer Fig. 2. Water was also sampled from the drainage canals and waterways at the study site. The location of each soil and water sampling site was recorded using a Geographical Positioning System (GPS).

Laboratory analyses: Soil $\mathrm{pH}$ was determined in water using soil to solution ratio of $1: 2.5$, while Electrical Conductivity (EC) was carried out using saturated paste. Cation Exchange Capacity (CEC) was determined by $1 \mathrm{M} \mathrm{NH}_{4} \mathrm{OAc}$ solution buffered at pH 7 (Soil Survey Laboratory Staff, 1992). 


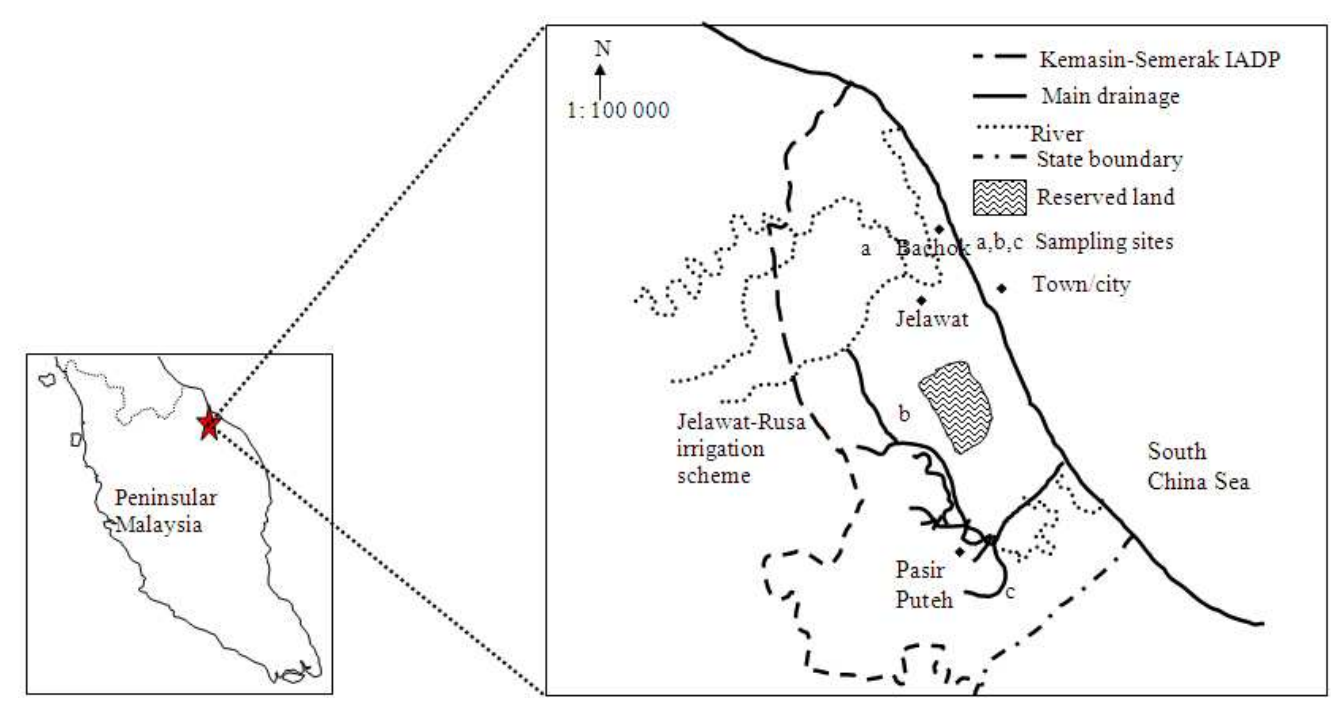

Fig. 2: Location of the study area

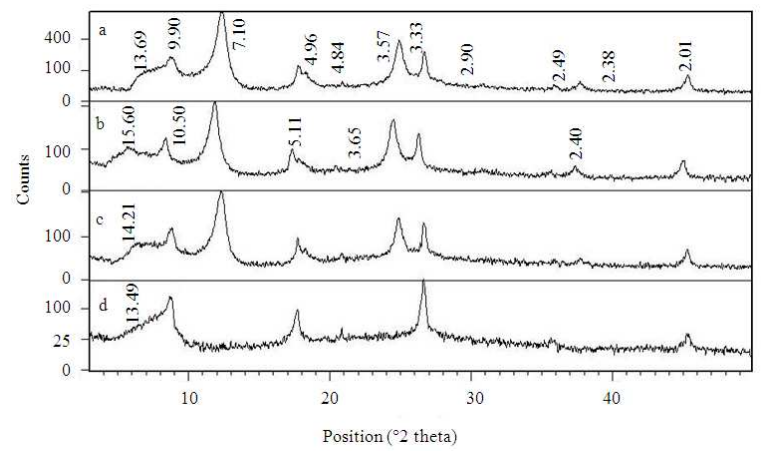

Fig. 3: XRD diffractograms of the treated clay fraction of the soil (a) Mg-sat; (b) Mg-glycolated; (c) Ksat; (d) K-heated

The basic cations ( $\mathrm{Ca}, \mathrm{Mg}, \mathrm{K}$ and $\mathrm{Na}$ ) in the $\mathrm{NH}_{4} \mathrm{OAc}$ solution were determined by Atomic Absorption Spectrophotometer (AAS). Exchangeable Al was extracted by $1 \mathrm{M} \mathrm{KCl}$ and the $\mathrm{Al}$ in the solution was determined by AAS. Total carbon (TC) was analyzed by the dry combustion method using a CNS analyzer. For the soils under study, calcium carbonate $\left(\mathrm{CaCO}_{3}\right)$ was absent. Therefore, the value of carbon obtained by CNS analyzer is close if not equivalent to Organic Carbon (OC).

Total $\mathrm{N}$ was determined by the Kjeldahl method and available $\mathrm{P}$ by the Bray 2 method. Soil available $\mathrm{P}$ was extracted with a mixture of $\mathrm{HCl}$ and $\mathrm{NH}_{4} \mathrm{~F}$ (Kuo, 1996). The soils for texture analysis were treated with hydrogen peroxide so as to remove organic matter. Particle-size distribution was determined by successive sedimentation (Soil Survey Laboratory Staff, 1992).
The clay fraction from the mechanical analysis was kept for mineralogical analysis. The clay treatments were $\mathrm{Mg}, \mathrm{Mg}$-glycol, $\mathrm{K}$ and $\mathrm{K}$-heated at $550^{\circ} \mathrm{C}$. These treatments were necessary in order to identify smectite, vermiculite and/or mica-mixed layers in the sample. The minerals in the clay fraction were identified by XRD analysis using Philips PW3440/60 X'Pert Pro.

\section{RESULTS}

Physico-chemical properties of the soils: Table 1 shows the soil chemical properties at selected points from three locations where detailed studies were carried out (locations a, b and c), while Fig. 3 identifies the minerals present in the clay fraction of the soil. At these locations, a pyrite layer occurred at different depths Fig. 4. The sediments below the pyritic layer are almost similar in terms of their physico-chemical properties. The soils are low in $\mathrm{pH}$, ranging from 3.244.89 and contain remarkably high amount of exchangeable $\mathrm{Al}\left(>5 \mathrm{cmol}_{\mathrm{c}} \mathrm{kg}^{-1}\right)$. The $\mathrm{pH}$ values less than 3.5 are indicative of high acidity associated with the occurrence of pyrite/jarosite. In general, exchangeable bases present in the soils is low and so is the CEC, reflecting the mineralogy dominated by kaolinite and mica.

Mineralogical properties: Data on mineralogical properties of the clay fraction of acid sulfate soils would be useful during discussion on the effects of soil acidity on soil weathering. Figure 3 shows the XRD diffractograms of the treated clay fraction of the soil under study. 
Am. J. Agri. \& Biol. Sci., 6 (3): 393-402, 2011

Table 1: Chemical properties of the soils

\begin{tabular}{|c|c|c|c|c|c|c|c|c|c|c|c|c|}
\hline \multirow{3}{*}{\multicolumn{2}{|c|}{ Sample Depth $(\mathrm{cm})$}} & \multirow[b]{3}{*}{$\mathrm{pH}$} & \multirow[b]{3}{*}{$\mathrm{EC}(\mathrm{dS} / \mathrm{m})$} & \multicolumn{9}{|c|}{ Exchangeable Cations } \\
\hline & & & & \multirow[b]{2}{*}{$\mathrm{K}$} & \multirow[b]{2}{*}{$\mathrm{Ca}$} & \multicolumn{4}{|c|}{$\left(\mathrm{cmol}_{\mathrm{C}} / \mathrm{kg}\right)$} & \multirow{2}{*}{$\begin{array}{l}\text { Avail. P } \\
(\mathrm{mg} / \mathrm{kg})\end{array}$} & \multicolumn{2}{|l|}{$(\%)$} \\
\hline & & & & & & $\mathrm{Mg}$ & $\mathrm{Al}$ & CEC & Ext. Fe & & Total N & Total C \\
\hline \multirow[t]{4}{*}{ 1(a) } & $0-15$ & 4.44 & 0.14 & 1.07 & 0.57 & 0.26 & 5.10 & 11.64 & 1.96 & 18.55 & 0.37 & 4.64 \\
\hline & $15-30$ & 4.16 & 0.12 & 0.54 & 0.56 & 0.16 & 6.71 & 10.36 & 1.11 & 18.48 & 0.18 & 1.68 \\
\hline & $30-45$ & 4.03 & 0.10 & 0.50 & 0.73 & 0.20 & 6.78 & 9.64 & 1.06 & 16.80 & 0.10 & 1.11 \\
\hline & $45-60$ & 4.01 & 0.08 & 0.63 & 0.83 & 0.36 & 7.87 & 10.79 & 0.43 & 134.40 & 0.21 & 6.29 \\
\hline \multirow[t]{5}{*}{ 2(a) } & $0-15$ & 4.24 & 0.10 & 1.23 & 2.97 & 1.67 & 2.66 & 8.36 & 2.65 & 16.66 & 0.17 & 1.96 \\
\hline & $15-30$ & 4.50 & 0.08 & 0.83 & 4.12 & 1.97 & 1.36 & 7.64 & 1.90 & 19.81 & 0.12 & 1.06 \\
\hline & $30-45$ & 4.89 & 0.10 & 0.88 & 7.09 & 2.15 & 0.63 & 9.43 & 1.51 & 11.62 & 0.11 & 1.40 \\
\hline & $45-60$ & 4.47 & 0.09 & 0.96 & 5.53 & 2.11 & 0.56 & 13.93 & 3.40 & 15.89 & 0.12 & 2.13 \\
\hline & $60-75$ & 4.17 & 0.15 & 1.29 & 8.17 & 2.19 & 1.12 & 12.14 & 2.61 & 19.81 & 0.19 & 4.32 \\
\hline \multirow[t]{4}{*}{$3(\mathrm{~b})$} & $0-15$ & 3.50 & 0.12 & 0.76 & 0.68 & 0.42 & 6.54 & 15.86 & 1.28 & 8.12 & 0.27 & 6.42 \\
\hline & $15-30$ & 3.52 & 0.17 & 0.52 & 0.45 & 0.42 & 6.45 & 13.64 & 0.49 & 9.31 & 0.14 & 2.68 \\
\hline & $30-45$ & 3.51 & 0.16 & 0.56 & 0.41 & 0.43 & 4.40 & 10.29 & 0.02 & 10.78 & 0.92 & 1.39 \\
\hline & $45-60$ & 3.23 & 0.18 & 0.48 & 0.50 & 0.52 & 7.61 & 27.43 & 0.13 & 10.64 & 0.20 & 8.76 \\
\hline \multirow[t]{4}{*}{ 4(b) } & $0-15$ & 3.42 & 0.04 & 0.47 & 0.76 & 0.22 & 5.81 & 12.50 & 0.25 & 11.97 & 0.18 & 2.34 \\
\hline & $15-30$ & 3.21 & 0.06 & 0.52 & 0.47 & 0.18 & 4.47 & 9.79 & 0.24 & 9.73 & 0.11 & 1.25 \\
\hline & $30-45$ & 3.85 & 0.06 & 0.42 & 0.52 & 0.11 & 3.19 & 8.29 & 0.26 & 9.38 & 0.72 & 0.42 \\
\hline & $45-60$ & 3.72 & 0.06 & 0.40 & 0.35 & 0.09 & 2.87 & 7.71 & 0.15 & 10.01 & 0.66 & 0.37 \\
\hline \multirow[t]{4}{*}{$5(\mathrm{c})$} & $0-15$ & 4.01 & 0.06 & 0.76 & 0.49 & 0.23 & 2.58 & 19.64 & 0.27 & 18.62 & 0.36 & 6.78 \\
\hline & $15-30$ & 3.80 & 0.08 & 0.43 & 0.44 & 0.14 & 6.04 & 13.64 & 0.10 & 10.92 & 0.14 & 2.53 \\
\hline & $30-45$ & 3.36 & 0.14 & 0.54 & 0.40 & 0.20 & 9.12 & 20.93 & 0.33 & 14.28 & 0.24 & 8.71 \\
\hline & $45-60$ & 3.24 & 0.19 & 0.36 & 0.35 & 0.23 & 3.36 & 20.36 & 0.12 & 11.62 & 0.24 & 7.91 \\
\hline \multirow[t]{4}{*}{$6(c)$} & $0-15$ & 3.84 & 0.04 & 0.82 & 0.34 & 0.28 & 1.96 & 16.07 & 0.12 & 14.28 & 0.25 & 5.26 \\
\hline & $15-30$ & 3.61 & 0.04 & 0.45 & 0.41 & 0.12 & 1.79 & 11.93 & 0.23 & 9.87 & 0.12 & 2.07 \\
\hline & $30-45$ & 3.60 & 0.04 & 0.39 & 0.35 & 0.09 & 1.28 & 8.57 & 0.53 & 10.36 & 0.87 & 0.94 \\
\hline & $45-60$ & 3.20 & 0.02 & 0.16 & 0.32 & 0.06 & 1.04 & 3.67 & 0.54 & 15.75 & 0.05 & 0.89 \\
\hline \multirow[t]{4}{*}{$7(\mathrm{c})$} & $0-15$ & 4.02 & 0.34 & 1.35 & 0.71 & 0.54 & 7.86 & 25.43 & 0.11 & 10.22 & 0.51 & 16.00 \\
\hline & $15-30$ & 3.09 & 0.42 & 1.37 & 0.68 & 0.70 & 10.81 & 17.21 & 0.10 & 23.10 & 0.29 & 11.40 \\
\hline & $30-45$ & 3.86 & 0.14 & 1.06 & 1.37 & 1.66 & 36.80 & 30.93 & 0.62 & 27.58 & 0.46 & 30.32 \\
\hline & $45-60$ & 3.24 & 0.42 & 0.83 & 2.88 & 2.05 & 92.00 & 8.16 & 0.15 & 23.59 & 0.47 & 36.43 \\
\hline
\end{tabular}

Depth (m)

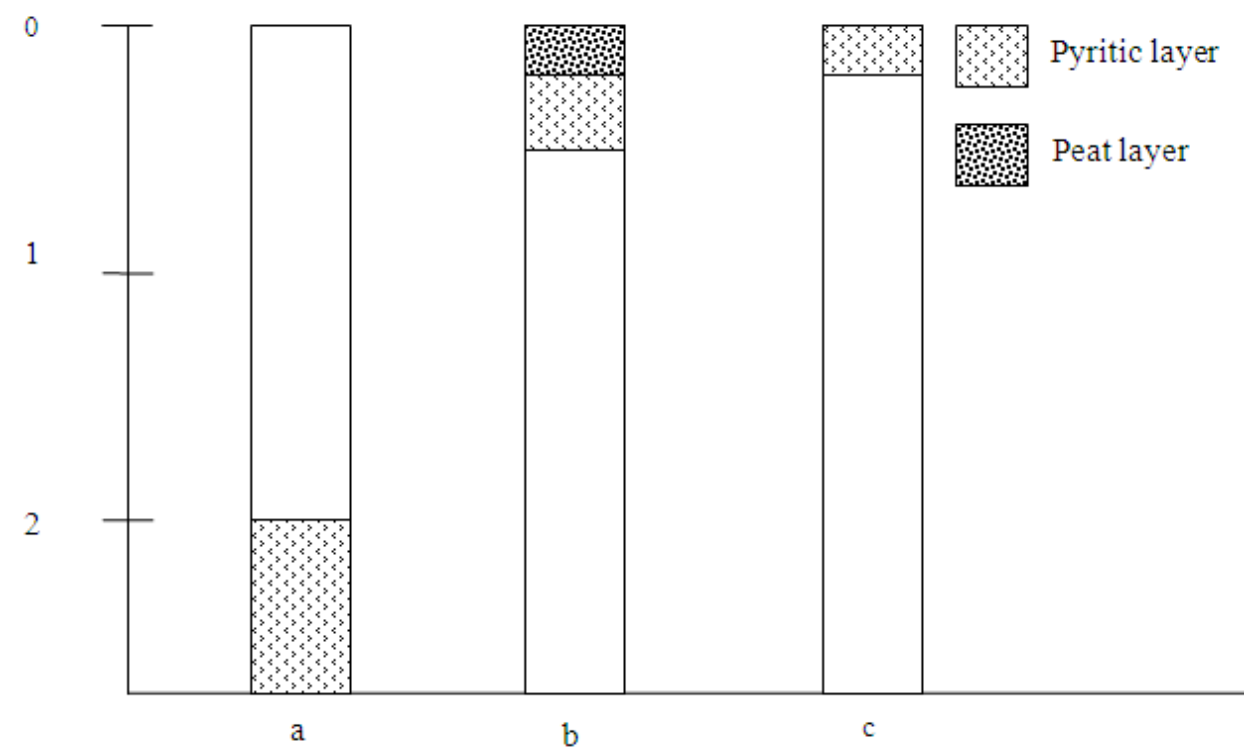

Fig. 4: The depth in soil profile below which pyrite occurs (at sites a, b and c) 
The Mg-treated sample gave XRD reflections at 9.90, $7.10,4.98,4.84,3.57$ and $3.33 \AA$, indicating the presence of mica $(9.90,4.98$ and $3.33 \AA$ ), kaolinite (7.10 and $3.57 \AA$ ) and gibbsite $(8.84 \AA)$. Glycolating the $\mathrm{Mg}$-saturated sample produced a weak peak at 15.60 А, indicating the presence of some smectite. The diffractogram of the K-saturated sample contains peak at about $12 \AA$ (meaning smectite collapsed by the $\mathrm{K}$ treatment) and when this sample was heated, $14 \AA$ peak did not appear. This is indicative of the absence of chlorite in the sample. As such, smectite occurring in the soil must have come from weathering of mica present in the soils. Extreme acidity accelerates weathering of mica.

The dominance of mica and kaolinite in the soil is consistent with the low CEC of the soils. Smectite has high CEC but it does not contribute much to the overall CEC of the soils as its amount is probably small.

Note that pyrite or jarosite was not detected by the XRD diffraction analysis. This is because during the process of separating the clay from the rest of the soil, these minerals were destroyed or oxidized by $\mathrm{H}_{2} \mathrm{O}_{2}$ which was used to remove the organic matter present in the soil.

\section{DISCUSSION}

Spatial distribution of the sediments containing pyrite: Pyrite-bearing sediments were found at many places in the Kelantan Plains. On closer examination, they are concentrated in the low lying areas (swales) adjacent to the sandy beach ridges throughout the Kemasin-Semerak IADP. This result is consistent with the findings of Soo (1975) and Steinkea et al. (2006). An imaginary line can now be sketched to separate soils containing pyrite from those without (riverine alluvium) as shown in Figure 5. Pyrite occurs in the soils to the east of the line and this so-called pyrite border, is consistent with the areas demarcated for acid sulfate soils found earlier. Therefore, we can say that this line was more or less the former shoreline about 6,000 years $\mathrm{BP}$ and that the plain starting from this line eastwards was under the sea during that particular period of its history. This kind of information has not been clearly explained or discussed by the earlier studies in the Kelantan Plains.

Changes of pyritic layer with depth: Figure 4 shows the distribution of pyritic layers with depth in the soil profiles located within the Kemasin-Semerak IADP. This figure was drawn based on data obtained from the field work within the study area in 2009. Some of the locations where pyrite was present in the sediments are marked as bold stars Fig. 5. Using various methods we were able to locate the depth of the pyritic layer. For the sake of discussion in this study, the pyritic layer occurs at three conspicuous depths, namely below $2 \mathrm{~m}$, between $0-50 \mathrm{~cm}$ and in the topsoil, which is about 15 $\mathrm{cm}$ depth Fig. 4. By and large, the first type was found mostly at location a (the northern part), the second type was found at location $b$ (the partially drained peaty area-the middle part) and the third type was found at location c (southern part) (Table 1 and Fig. 5).

The depth of the pyritic layer in soils of the northern part of the study area (near downtown Jelawat) was too deep to be determined by soil auger. For this location, the samples for this study were taken near the drainage canals. During the time of the survey, the local authority was cleaning, widening and digging the canals for maintenance purposes. The materials from the canal bed were dug up and placed on the shoulders of the canals. These samples were collected and left to dry for a few days to check if they contained pyrite. On drying, clear yellowish mottles appeared within the samples and the $\mathrm{pH}$ was about 3 . The yellowish mottles were actually jarosite being formed from the oxidation of pyrite (Shamshuddin and Auxtero, 1991; Shamshuddin et al., 2004a; Shamshuddin, 2006). The drainage canals were more than $2 \mathrm{~m}$ deep. Some ordinary samples for physico-chemical analyses from the area were also taken by using the auger. The results of the analyses of these samples are presented in Table 1. It was found that the soils from the top $75 \mathrm{~cm}$ had $\mathrm{pH}$ values above 3.5 , giving the impression that the soils might not be acid sulfate soils.

The soils within the partially drained area were overlain by peaty materials Fig. 2. During the field work, samples were taken according to depth at the interval of $15 \mathrm{~cm}$ and subsequently analyzed to determine their physico-chemical properties. It was found that within $50 \mathrm{~cm}$ depth, the $\mathrm{pH}$ of the soils was generally below 3.5, consistent with the $\mathrm{pH}$ value for Sulfaquepts (acid sulfate soils) as defined by soil taxonomy (Soil Survey Staff, 2010). A quick look at the air-dried samples in the laboratory indicated the presence of yellowish jarosite mottles.

Soils in the southern part of study area were mostly acidic throughout the profiles. At some locations, yellowish jarosite mottles appeared on the surface of the soils. Clearly, in these soils pyrite occurs within the topsoil. Much of the area had been cropped to paddy, but they were abandoned ever since the soils had become very acid and $\mathrm{Al}^{3+}$ was present at toxic levels for rice production. Currently, the plant species growing in abandoned paddy fields is purun (Eleocharis dulcis), which is Al-tolerant (Muhrizal et al., 2006). 


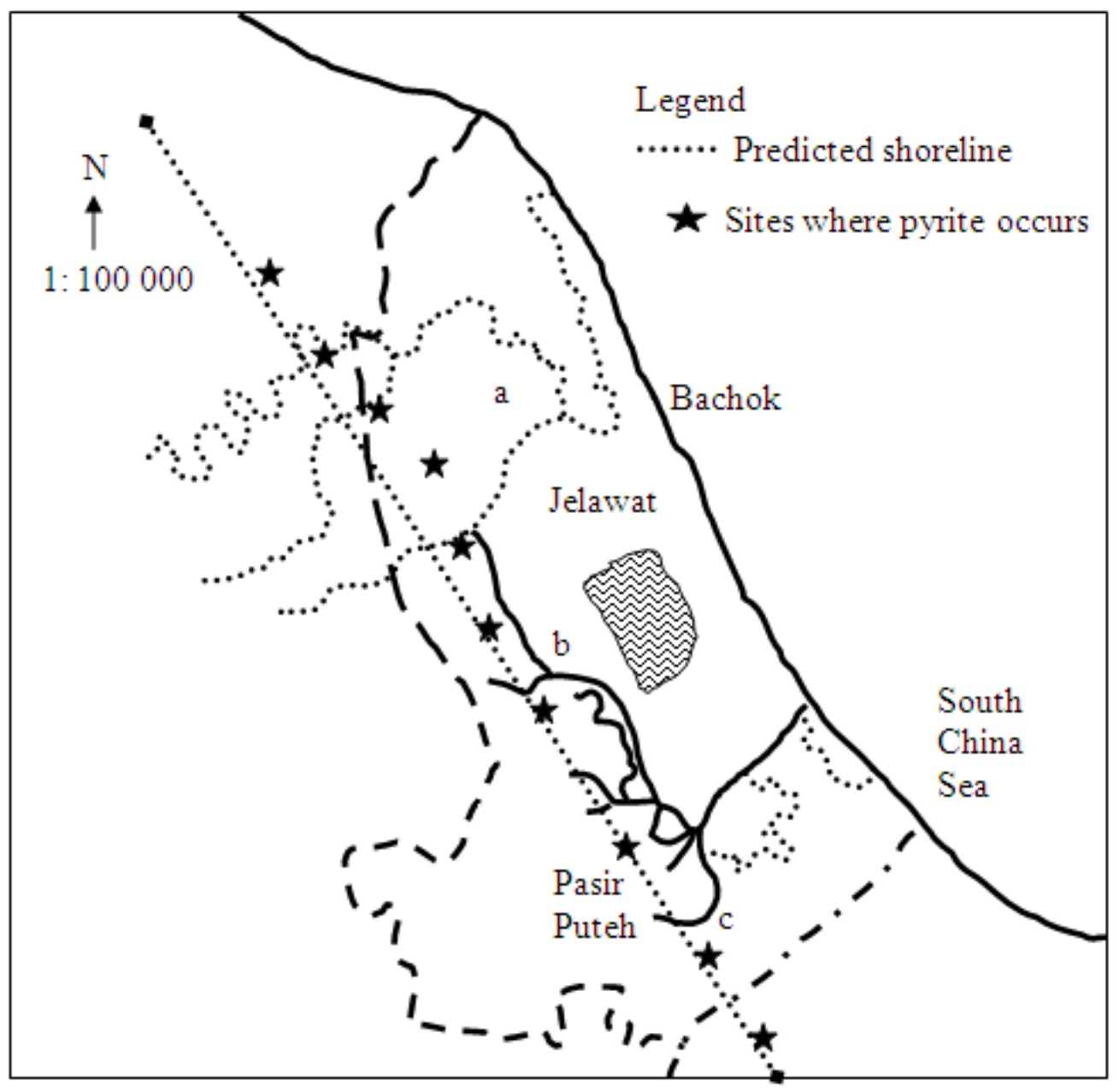

Fig. 5: The predicted position of the shoreline in the Kelantan Plains about 6000 years BP

Conceptual modeling of the pyritization process: Pyrite forms when sulfate $\left(\mathrm{SO}_{4}{ }^{2-}\right)$ from seawater and ferric ions $\left(\mathrm{Fe}^{3+}\right)$ from marine sediments are reduced to sulfide $\left(\mathrm{S}^{2-}\right)$ and $\mathrm{Fe}^{2+}$ ions, respectively. These reactions occur under anaerobic conditions (extremely reducing) where microorganisms feeding on organic matter present in the sediments play an important role in the reduction process.

Under flooded condition and in the presence of organic matter $\mathrm{Fe}^{3+}$ ions in the solution are readily reduced to $\mathrm{Fe}^{2+}$ ions with the help of microbes (Ivarson et al., 1982; Konsten et al., 1994). At the study site, organic matter needed for the reduction process could have been provided by the gelam and nipah palm, which are growing in the area until today. Reduction of sulfate to sulfide also requires the help of microbes living in the sediments (Poonam et al., 2010). The microbes responsible for this reaction are the
Desulfovibro desulfuricans (Bloomfield and Coulter, 1973; Ivarson et al., 1982). The condition in the area must have been strongly reducing where Eh was less than $-220 \mathrm{mV}$.

If a soil containing pyrite is drained, the pyrite undergoes oxidation according to the following equation (Dent, 1986):

$$
\begin{aligned}
& \mathrm{FeS}_{2(\mathrm{~s})}+15 / 4 \mathrm{O}_{2(\mathrm{aq})}+7 / 2 \mathrm{H}_{2} \mathrm{O}_{(\mathrm{l})} \rightarrow \mathrm{Fe}^{\mathrm{III}}(\mathrm{OH})_{3(\mathrm{~s})}+2 \mathrm{SO}_{4}{ }^{2-} \\
& (\mathrm{aq})+4 \mathrm{H}_{(\mathrm{aq})}^{+}
\end{aligned}
$$

The acidity so produced would pollute the surrounding areas. This is a cause of concern in the study area.

Figure 6 shows the hypothetical landscape when and where pyritization processes could have taken place. The sea level at and around the Kelantan Plains about 6000 years BP was 3-5 m higher than at present. 
Am. J. Agri. \& Biol. Sci., 6 (3): 393-402, 2011

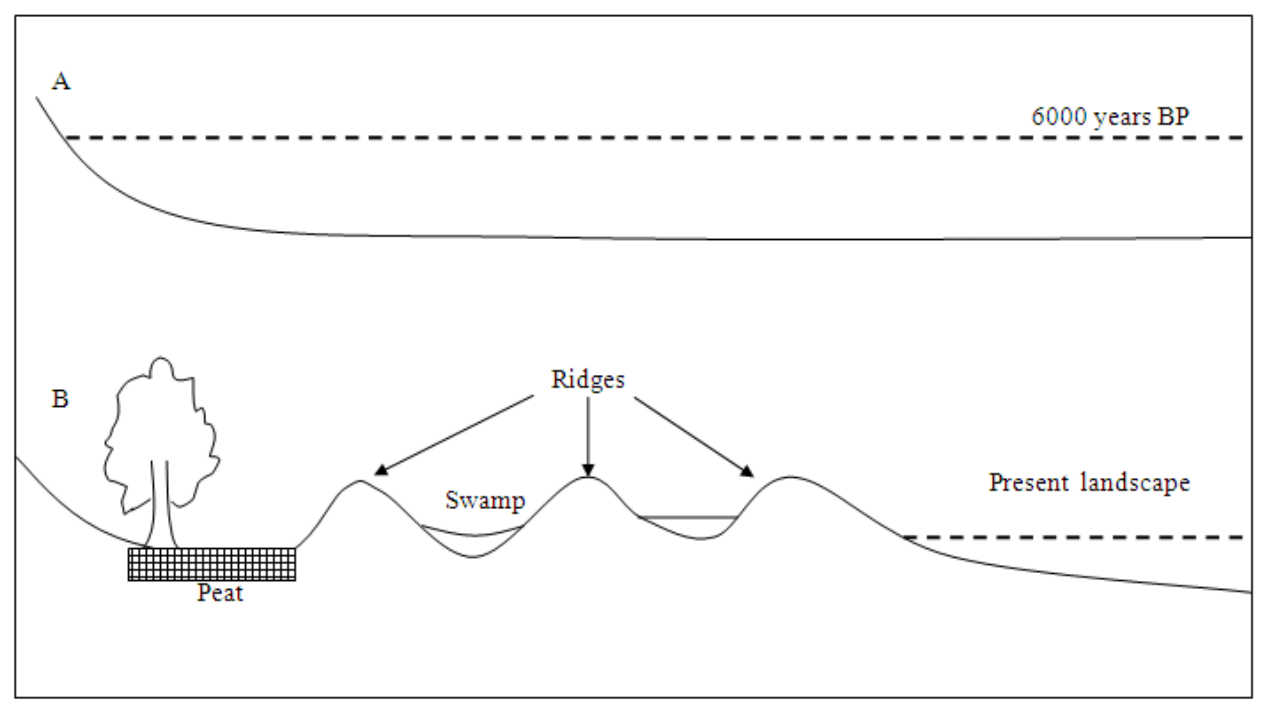

Fig. 6: The predicted sea level about 6,000 years BP (A) and the present landscape (B) in the Kelantan Plains

The sea level here might have been similar to what had been proposed for the Bangkok Plains during that period of history by Pons et al. (1982). Carbon dating of the oldest sediments in the Sunda Shelf has given an age of about 6,000 years (Haile, 1970). This means that much of the present coastal plains in Kelantan were under the sea at that time. Pyrite found in the study area was probably formed when the sea was at its highest level with the help of microbes (Bloomfield and Coulter, 1973; Ivarson et al., 1982). The process of pyritization can be summarized as follows:

$\mathrm{Fe}^{3+}$ (present in the marine sediments) $\rightarrow \mathrm{Fe}^{2+}$ $\mathrm{SO}_{4}{ }^{2-}$ (from seawater) $\rightarrow \mathrm{S}^{2-}$

The reduction of the ferric ions requires anaerobic conditions (Konsten et al., 1994) and so is sulfate ion.

Then, the ferrous and sulfide ions had reacted to form pyrite $\left(\mathrm{FeS}_{2}\right)$. After a long period of time (probably a few thousand years), the amount of pyrite formed could be substantial in amount. The overall reaction for the formation of pyrite in the soils of the Kelantan Plains can be described by the following Equation (Pons et al., 1982):

$\mathrm{Fe}_{2} \mathrm{O}_{3}+4 \mathrm{SO}_{4}{ }^{2-}+8 \mathrm{CH}_{2} \mathrm{O}+1 / 2 \mathrm{O}_{2} \rightarrow 2 \mathrm{FeS}_{2}+8 \mathrm{HCO}_{3}{ }^{-}$ $+4 \mathrm{H}_{2} \mathrm{O}$

The above equation shows that it needs sufficient amount of organic matter for the reduction process to proceed without interruption. In the area under study, Gelam and nipah palm were found to be abundant.
Furthermore, oxygen must be available for the microbes that help convert sulfate to sulfide to survive under anaerobic condition.

This reaction is presumed to have occurred while the sea level was higher than that at present as shown in Fig. 6A. As the sea prograded (Raj, 2009), sandy beach ridges interspersed with swales were created (Roslan $e t$ al., 2010). Some of the soils in the swales between the ridges Fig. 6B contain pyrite, which was confirmed during the field work carried out for this study.

As mentioned earlier, soils at location a Fig. 2 and 4 have pyritic layer deep down the soil profiles. How did this come about? The plausible explanation for the pyritization process at that location is now given. In the northern part of the study area, in the vicinity of Jelawat, the area bordering the shoreline was probably at a higher level than that of the southern part. The alluvial materials were found to be sandy and therefore porous. Seawater was able to seep through the porous riverine alluvial materials containing Fe-oxides at a few meters below the surface. As Table 1 shows, extractable $\mathrm{Fe}$ is present in high amount in the soils of the area. Organic matter required by microbes is probably present in sufficient amount. Given time, pyrite was slowly but surely mineralizing in the hydromorphic sediments where Fe and seawater were present.

At location b, the present landscape is totally different from that of a. Here, due some unknown reasons, swamps were formed when the sea was prograding (Raj, 2009). The water in these swamps was probably brackish due to intrusion of seawater from time to time, most probably during the monsoon 
months of November to January. Gelam and nipah palm, probably have been growing since time immemorial provided enough organic matter for the microbes to survive while converting sulfate to sulfide. If sufficient amount of $\mathrm{Fe}^{3+}$ is available (Table 1), pyrite is consequently mineralized in the sediments. As the condition was waterlogged, the organic matter from the plant species growing in the swamps had accumulated, forming an organic layer above the mineral soils. Hence, the areas are now having soils containing pyrite overlain by peaty materials. A big portion of this area has been gazette as forest reserved, although it has been partly drained. The age of these deposits can be close to that of the sediments forming the oldest sandy beach ridges in the coastal plains of about 6,000 years BP (Kefu and Tegu, 2009).

In the southern part (location c), the area was rather flat and located close to the present shoreline. The area was not swampy, but flooded during the rainy season. Gelam and nipah palm could have flourished here, which survive till the present day. Seawater must have reached this area a few thousand years ago, during which pyrite was mineralized according to the mechanism mentioned above. During the field work, we found yellowish jarosite mottles appearing in the topsoil in some localities.

Evidence for the rise of sea level during the Holocene: By locating the sites where pyrite-bearing sediments were found, areas containing pyrite (acid sulfate soils) can be delineated. An imaginary line can be drawn to separate acid sulfate soils and riverine alluvial materials, which is shown in Fig. 5. This line can be assumed to be the position of the shoreline about 6,000 years BP. From the information given earlier, pyritization of the sediments requires sufficient amount of seawater to supply sulfate. It means that for the pyrite to be formed in the area, the sea level must have risen a few meters above the present. As such, we can use the presence of pyrite as another evidence for the rise of sea level in the Kelantan Plains during the Holocene. This argument on sea level rise during the Holocene is consistent with the evidence put forward by others, which is based on geological records of the area (Tjia et al., 1977; Woodroffe and Horton, 2005).

Implication of the sediments containing pyrite: Sediments containing pyrite could be a major problem to the livelihood of the people living in the surrounding areas. Pyrite itself is stable under its natural condition (submerged under water). When the soils containing it are drained for development (e.g., for rice cultivation), the pyrite is exposed to the atmospheric conditions and subsequently oxidized, releasing high amount of acidity. The low $\mathrm{pH}$ that followed could accelerate the dissolution of silicates in the soils that result in the release of toxic metals, such as $\mathrm{Al}^{3+}$ and $\mathrm{Fe}^{3+}$ into the soils and waterways that kill plants and aquatic life alike.

The above phenomena have taken place in the area under study. It was observed that some paddy fields in the area are degraded by the soil acidity and extreme level of $\mathrm{Al}^{3+}$ and $\mathrm{Fe}^{3+}$ concentration. The low $\mathrm{pH}$ and high $\mathrm{Al}^{3+}$ concentration are indicated by the abundant of acid-tolerant purun species growing in the drainage canals near the paddy fields (Muhrizal et al., 2006).

At the onset of monsoon season the water in the paddy fields is reddish in color showing the existence of Fe-oxides (Shamshuddin, 2006). Therefore, growing rice on such unproductive land is uneconomical as the yield is far below the national average of $3.8 \mathrm{t} / \mathrm{ha}$. In order to get a good crop of rice from these paddy fields dolomitic limestone has to be applied by the farmers at an adequate level (Suswanto et al., 2007a; 2007b). This is probably the main reason for the existence of severe poverty in the area for such a long time. Plan is underway to alleviate the infertility of the soils in the area.

\section{CONCLUSION}

Soils containing pyrite occur sporadically in the Kelantan Plains, Peninsular Malaysia. The pyrite in the soils occurs at varying depth; it is below $2 \mathrm{~m}$ in the northern part of the plains and on the surface horizon in the soils in the southern part. In the middle where the area is low lying, the pyritic layer is overlain by peaty materials. Oxidation of pyrite has caused untold damage to the productivity of the paddy soils in the area. This pyrite is assumed to have been mineralized about 6,000 years BP when the sea level rose $3-5 \mathrm{~m}$ above the present. An imaginary line can be drawn using spatial distribution of pyrite to indicate the probable position of the shoreline when the sea level was at its highest. The occurrence of pyrite in the soils, which are classified as acid sulfate soils, can be used as an evidence of sea level rise in the plains during the Holocene.

\section{ACKNOWLEDGEMENT}

The researchers would like to thank University Putra Malaysia for financial and technical support during the conduct of the research. This research was financed by the Fundamental Research Grant Scheme (02-11-08-717FR) provided by the Ministry of Higher Education, Malaysia. 


\section{REFERENCES}

Anda, M., A.B. Siswanto and R.E. Subandiono, 2009. Properties or organic and acid sulfate soils and water of a 'reclaimed' tidal backswamp in Central Kalimantan, Indonesia. Geoderma, 149: 54-65. DOI: 10.1016/j.geoderma.2008.11.021

Auxtero, E.A. and J. Shamshuddin, 1991. Growth of oil palm (Elaeis guinensis) seedlings as affected by water regime and Al. Plant and Soil, 137:243-257. DOI: $10.1007 / \mathrm{BF} 00011203$

Bloomfield, C. and J.K. Coulter, 1973. Genesis and management of acid sulfate soils. Adv. in Agron., 25: 265-320. DOI: 10.1016/S0065-2113(08)60783-X

Dent, D., 1986. Acid Sulphate Soils: A Baseline for Research and Development. 1st Edn., International Institute for Land Reclamation and Improvement, Wageningen, ISBN: 9070260980, pp: 204.

Eko Yulianto, W.S. Sukaptib, A.T. Rahardjoc, Dardji Noeradic and D.A. Siregarb et al., 2004. Mangrove shoreline responses to Holocene environmental change, Makassar Strait, Indonesia. Rev. Palaeobotany Palynol., 131: 251-268. DOI: 10.1016/j.revpalbo.2004.03.009

Geyh, M. A., H. Streif and H.R. Kudrass, 1979. Sealevel changes during the late Pleistocene and Holocene in the Strait of Malacca. Nature, 278: 441-443. DOI: 10.1038/278441a0

Haile, N.S., 1970. Radio carbon dates of Holocene emergence and submergence in Tembelau and Bungural Islands, Sunda Shelf, Indonesia. Bull. Geol. Soc. Malaysia, 3: 135-137. ISSN: 01266187

Ivarson, K.C., J.C. Ross and N.M. Miles, 1982. Microbiological Transformation of Sulfur and their Applications to Acid Sulfate Soils and Tidal Marshes. In: Acid Sulfate Weathering, Kittrick, J.A., D.S. Fanning and L.R. Hossner (Eds.). Soil Science Society of America, Madison, pp: 57-76. ISBN: 0891187707

Kefu, Y. and C. Tegu, 2009. Beach sediments from Northern South China Sea suggest high and oscillating sea levels during the late Holocene. Earth Sci. Frontiers, 16: 138-145. DOI: 10.1016/S1872-5791(08)60110-4

Konsten, C.J.M., N.V. Breemen, S. Suping, I.B. Aribawa and J.E. Groenenberg, 1994. Effect of flooding on $\mathrm{pH}$ of rice producing, acid sulfate soil in Indonesia. Soil Sci. Soc. Am. J., 58: 871-883. DOI: $10.2136 /$ sssaj 1994.03615995005800030035x

Kuo, S., 1996. Phosphorus. In: Method of Soil Analysis. Part 3-Chemical Methods, Sparks, D.L., A.L. Page, P.A. Helmke, R.H. Loeppert and P.N. Soltanpour (Eds.). SSSA-ASA, Wisconsin, pp: 869-919. ISBN: 0-89118-825-8
Mohd, T.M., Yusuff, O.H. Ahmed and Nik M.A. Majid, 2009. Effect of enhancing urea-humic acid mixture with refined acid sulphate soil. Am. J. Applied Sci., 6: $\quad 1892-1896 . \quad$ DOI: 10.3844/ajassp.2009.1892.1896

Muhrizal, S., J. Shamshuddin, I. Fauziah and M.H.A. Husni, 2006. Changes in iron-poor acid sulfate soil upon submergence. Geoderma, 131: 110-122. DOI: 10.1016/j.geoderma.2005.03.006

Pons, L.J., N. Van Breemen and P.M. Driessen, 1982. Physiography of Coastal Sediments and Development of Potential Acidity. In: Acid Sulfate Weathering, Kittrick, J.A., D.S. Fanning and L.R. Hossner (Eds.). J. Soil Science Society of America, Madison, pp: 1-18. ISBN: 0891187707

Poonam, N., G.G. Pandit, A.R. Thakur and S.R. Chaudhuri, 2010. Comparative study of soluble sulfate reduction by bacterial consortia from varied regions of India. Am. J. Environ. Sci., 6: 152-158. DOI: 10.3844/ajessp.2010.152.158

Raj, J.K., 2009. Geomorphology. In: Geology of Peninsular Malaysia, Hutchison, C.S. and N.K. Tan (Eds.). University of Malaya and Geol. Society of Malaysia, Kuala Lumpur, pp: 5-29. ISBN 97898344296-6-9

Roslan, I., J. Shamshuddin, C.I. Fauziah and A.R. Anuar, 2010. Occurrence and properties of soils on sandy beach ridges in the Kelantan-Terengganu Plains, Peninsular Malaysia. Catena, 83: 55-63. DOI: $10.1016 /$ j.geoderma.2005.03.006

Shamshuddin, J. and E.A. Auxtero, 1991. Soil solution composition and mineralogy of some active acid sulfate soils in Malaysia as affected by laboratory incubation with lime. Soil Sci., 152: 365-376. DOI: 10.1097/00010694-199111000-00008

Shamshuddin, J., 2006. Acid Sulfate Soil in Malaysia. 1st Edn., UPM Press, Serdang, ISBN: 9832871875 , pp: 127.

Shamshuddin, J., S. Muhrizal, I. Fauziah and E. Van Ranst, 2004a. A laboratory study of pyrite oxidation in acid sulfate soils. Commun. Soil Sci. and Plant Anal., 35: 117-129. DOI: 10.1081/CSS120027638

Shamshuddin, J., S. Muhrizal, I. Fauziah and M.H.A. Husni, 2004b. Effects of adding organic materials to an acid sulfate soil on the growth of cocoa (Theobroma cacao L.) seedlings. Sci. Total Environ., 323: 33-45. DOI: 10.1016/j.geoderma.2005.03.006

Soil Survey Laboratory Staff, 1992. Soil Survey Laboratory Methods Manual. Soil Survey Investigation Report 42, ver 2.0. United States Department of Agriculture. Unpublished, Washington DC. 
Soil Survey Staff, 2010. Keys to Soil Taxonomy. United States Department of Agriculture, Washington DC.

Soo, S.W., 1975. Semi-Detailed Soil Survey of the Kelantan Plains. Ministry of Agriculture and Rural Development, Unpublished, Kuala Lumpur.

Steinkea, S., H.-Y. Chiub, P.-S. Yuc, C-C. Shenb and H. Erlenkeuserd et al., 2006. On the influence of sea level and monsoon climate on the southern South China Sea freshwater budget over the last 22,000 years. Quaternary Sci. Rev., 25: 1475-1488. DOI: 10.1016/j.quascirev.2005.12.008

Suswanto, T., J. Shamshuddin, S.R. Syed Omar, Peli Mat and C.B.S., 2007a. Effects of lime and fertilizer application in combination with water management on rice (Oryza sativa) cultivated on an acid sulfate soil. Malay J. Soil Sci., 11: 1-16. ISSN 1394-7990
Suswanto, T., J. Shamshuddin, S.R. Syed Omar, Peli Mat and C.B.S. Teh, 2007b. Alleviating an acid sulfate soil cultivated to rice (Oryza sativa) using ground magnesium limestone and organic fertilizer. J. Soil Environ., 9: 1-9. ISSN: 1410-7333

Tjia, H.D., 1996. Sea-level changes in the tectonically stable Malay-Thai Peninsula. Quaternary Int., 31: 95-101. DOI: 10.1016/1040-6182(95)00025-E

Tjia, H.D., S. Fujii and K. Kigoshi, 1977. Changes of sea level in South China Sea during the Quaternary. In: Malaysian and Indonesian coastal and offshore areas. United Nations ESCAP. CCOP Technical Publication 5, pp: 11-36. Unpublished.

Wan Noordin, W.D., 1980. Soil genesis on coastal plains, Perak, Peninsular Malaysia. DSc Thesis. Ghent: ITC, Ghent University.

Woodroffe, S.A. and B.P. Horton, 2005. Holocene sealevel changes in the Indo-Pacific. J. of Asian Earth Sci., 25: 29-43. DOI: 10.1016/j.jseaes.2004.01.009 